\title{
CORPOS RIZOMÁTICOS NA DIÁSPORA HETEROTÓPICO-SUBJETIVA DE UM COPO DE CÓLERA, DE RADUAN NASSAR
}

\author{
Jorge Alves Santana \\ Universidade Federal de Goiás \\ Goiânia, GO, BR
}

\section{Resumo}

Representações de processos de subjetivações e de espaços transversais são observadas e analisadas na narrativa Um copo de cólera, de Raduan Nassar. Entre vestígios da loucura, obtidos por uma atualização da imagem da Nau dos Loucos, nos enfrentamentos entre o bucolismo pastoral e a emergência da produtividade urbana, vai-se para a produção territorializada e desterritorializada de rostidades que demonstram aberturas para possibilidades de novos acordos afetivos, culturais e políticos, nos quais os sentidos da loucura se deslocam para realidades menos essencialistas e mais históricas.

Palavras-chaves: Um copo de cólera; bodies; Nau dos loucos; processos de subjetivações.

\section{RHIZOMATIC BODIES AND DIASPORIC SUBJECTIVE-HETEROTOPIC IN RADUAN NASSAR'S UM COPO DE CÓLERA}

\begin{abstract}
Representations of the process of subjectivity and transversal spaces are perceived and analyzed in Raduan Nassar's Um copo de cólera. Among traces of madness, obtained by an updating of the image of The ship of fools in the conflict between pastoral bucolism and the emergency of urban productivity, the study proceeds to the territorialized and deterritorialized production of faciality that reveal openings to possibilities of new emotional, cultural and political pacts in which the meaning of madness moves to less essentialist and more historical realities. Keywords: Um copo de cólera; bodies; ship of fools; process of subjectivities.
\end{abstract}

\begin{abstract}
A distância entre aquilo que precisamos saber para navegar e aquilo que sabemos ou cremos saber dos movimentos efectivos e possíveis dos outros é percebida como o elemento de "estranheza" dos outros, e a separação constitui-os como estranhos.

A vida fragmentada. Zygmunt Bauman, 2007, p. 133.

Talvez se pudesse dizer que certos conflitos ideológicos que animam as polêmicas de hoje em dia se desencadeiam entre os piedosos descendentes do tempo e os habitantes encarniçados do espaço.

Outros espaços. Michel Foucault, 2001, p. 411.
\end{abstract}

Por alguns momentos lá no quarto nós pare-
cíamos dois estranhos que seriam observados
por alguém, e este alguém era sempre eu e ela,
cabendo aos dois ficar de olho no que eu ia fa-
zendo.
Um copo de cólera. Raduan Nassar, 1978, p. 33 .

\section{Introdução}

A narrativa literária Um copo de cólera, de Raduan Nassar, é publicada em 1978. Alegoria dos encontros multiculturais de nossa contemporaneidade, abrange tanto o contexto estético quanto o sócio-político-cul-

\footnotetext{
"Jorge Alves Santana é Professor Associado II da Faculdade de Letras, da Universidade Federal de Goiás (UFG). Membro do Programa de Pós-Graduação em Letras e Linguística. Com Pós-Doutorado em Estudos Literários e Estudos Culturais pelo Pós-Lit da Universidade Federal de Minas Gerais (UFMG). E-mail: jorgeufg@bolcom.br.
} 
tural, no qual os heterogêneos e múltiplos espaços existenciais são colocados frente a frente em uma dialética dialogia, que nos permite entrever uma rede de negociações entre agentes sociais para que se alcance níveis de coexistência tolerável e produtiva.

Um homem e uma mulher, neste universo diegético, relacionam-se em um espaço campesino de encontro aparentemente bucólico e amoroso, como observamos em sua abertura:

E quando cheguei à tarde na minha casa lá no 27, ela já me aguardava andando pelo gramado, veio me abrir o portão pra que eu entrasse com o carro, e logo que saí da garagem subimos juntos a escada pro terraço, e assim que entramos nele abrir as cortinas do centro e nos sentamos nas cadeiras de vime, ficando com os olhos voltados pro alto do lado posto, lá onde o sol ia se ponde, e estávamos os dois em silêncio, quando ela me perguntou "que que você tem"? (NASSAR, 1978, p. 7-8)

Tal quadro accional nos é representado e expresso por uma enunciação com acentuados marcadores das culturas árabes, em sua frente libanesa, produzidos pelo encontro com a multiculturalidade brasileira. Que voz enunciativa nos orquestra esse universo diegético?

Raduan Nassar é oriundo do interior de São Paulo, de Pindorama, como acompanhamos no Cadernos de Literatura Brasileira, no 2, publicado pelo Instituto Moreira Salles. É o sétimo de dez filhos do casal libanês João Nassar e Chafika Cassis. Seus pais casaram-se em 1919, na aldeia de Ibel-Saki, no sul do Líbano. Imigraram para o Brasil em 1920, no período posterior à Primeira Guerra Mundial.

João Nassar se juntou a parentes que já estavam no Brasil e entrou para o ramo do comércio, no interior do Rio de Janeiro, como fez grande parte dos imigrantes libaneses que escolheram por conta própria, ou foram obrigados a escolher por questões geopolíticas de seu Líbano natal, o Brasil como porto seguro. Em seguida, fixaram-se no interior de São Paulo, progredindo nos negócios comerciais e com a preocupação constante em educar os filhos de modo sistemático na heterogênea cultura brasileira. Essa segunda fase é percebida quando a família se muda para a capital paulista e vários dos filhos frequentam cursos na Universidade de São Paulo e em associações midiático-literárias da cidade.

Importam-nos esses dados, supostamente extraliterários, devido ao enfoque multiculturalista de nossas reflexões. Assim, é válido sabermos que Raduan Nassar é descendente direto de uma família de imigrantes libaneses e quais foram os possíveis vetores de sua formação pessoal e profissional na cultura brasileira que, de modo simétrico ou assimétrico, geraram consequências na tessitura da ficção que aqui pretendemos analisar.

Os libaneses, correlatos do povo árabe, aportaram no Brasil a partir do final do século XIX. Essa imigração acentuou-se nas primeiras décadas do século XX, o que criou, no Brasil, a maior comunidade de imigrantes libaneses no mundo. Questões políticas sempre estremeceram a paz do povo libanês no que seria seu território nacional próprio. Vizinhos belicosos dinamizaram constantemente métodos de invasão e cooptação desse povo relativamente pacato do Oriente Próximo. Por outro lado, a dimensão heterogênea das instituições religiosas desse povo criava um peculiar elemento de distensão no Líbano.

Normalmente, ao lado das querelas políticas, a variabilidade religiosa teve papel importante no adensamento dos frequentes confrontos bélicos entre o Cristianismo, com suas várias ramificações, tais como Maronitas, Ortodoxos Gregos, Melquitas Greco-Católicos, Cristãos Armênios, Cristãos Assírios, Coptas e o Islamismo (Xiitas, Sunitas e Ismaelitas). Esses são alguns dos fatores determinantes do êxodo desse povo em constante movimento diaspórico. Sendo que as famílias mais abastadas costumavam migrar para os Estados Unidos e as mais humildes encontravam seu provisório, ou nem tanto assim, porto seguro no Brasil.

A aclimatação dos libaneses no Brasil deu-se também por meio de sua índole para a necessária atividade comercial em um país ainda predominantemente agrícola, portanto, ainda de economia precária, e da aparente tranquila recepção, feita pelos brasileiros, às várias etnias que por aqui aportaram, como nos ilustra minuciosamente Denise Fagundes Jardim, em seu estudo dobre a imigração arábe para o Brasil (1999, p, 49-93). Famílias libanesas, com frequência, habitavam os estados do Rio de Janeiro, São Paulo e Minas Gerais. Normalmente uma 
família desenvolvia meios para unir-se a outras famílias libanesas, o que formou um sólido grupamento em solo brasileiro, semelhante a outros povos, tais como japoneses, alemães, italianos e outros.

Apesar da decantada receptividade do povo brasileiro, a construção de um novo espaço social assume cores de exílio, com suas consequências de valores comportamentais pessoais e coletivos para o libanês, e exige esforços para que elementos da nova cultura não enfraqueçam ou mesmo destruam a tradição cultural desses imigrantes. Ações e contextos de retração e de exclusão usualmente são ativados nessas circunstâncias, para que a tradição e as particularidades da cartografia étnico-subjetiva mantenham-se minimamente intactas, ou em nível dialógico suportável diante das singularidades representadas pela outridade que se coloca no papel de anfitrião.

No entanto, nenhum tecido sócio-político-cultural sustenta-se pela regra da exclusão permanente de elementos que lhe possam ser estranhos. Movimentos de encontro, de interpenetração, de hibridização, de assimilação, surgem e tendem a minimizar os desencontros, a eugenia cultural, e a "guetização", advindos dos encontros/conflitos entre povos diferentes.

O caráter acima reclama-nos a validade de sua utilização, pois apesar de nosso ponto de partida ser a obra literária, consideramos saudável, do ponto de vista da metodologia transversal, colocá-la em uma rede dialógica de elementos sócio-culturais. Esta metodologia procura construir um espaço existencial em que os sentidos tomam sua aura estética e, ao mesmo tempo, dialética em relação aos elementos de contextos pragmáticos que lhe servem de base e de acolhida. Os valores dessa rede intra-extraliterária surgem-nos, então, quando acompanhamos a construção de corpos rizomáticos e de subjetivações possíveis na narrativa $U m$ copo de cólera, Raduan Nassar.

\section{Configuração de rostidades diásporicas e loucura subjetivo-social}

Um copo de cólera, de Raduan Nassar, é uma narrativa de tamanho singularmente reduzido. No entanto, sua força linguística, estilística e temática a coloca em pé de igualde, no plano de intensidade estético/temáti- ca, com narrativas já clássicas da Literatura Brasileira. Entre o romance e a novela, sua trama evoca o contexto de um chacareiro que praticamente se isola nos limites de sua chácara, envolvido com os trabalhos da criação animal e com o cultivo de vegetais para venda e consumo próprio. O narrador é o próprio protagonista. Sendo assim, vemos que os acontecimentos nos são narrados por quem os vive em sua dimensão intrapessoal e interpessoal; a vivência é, pois, intensa e há claro interesse subjetivo nas formações discursivas que possibilitam o relato.

O chacareiro não é um simples habitante do campo que vivencia o bucolismo de uma pastoral possível em plena época contemporânea. Ele demonstra ter conhecimentos de questões profundas sobre a existência humana, das relações entre campo e cidade, das relações entre gênero masculino e feminino e seus papeis na sociedade, bem como das necessidades heterogêneas de que suas subjetivações fazem uso.

A narrativa é dividida em partes que montam uma circularidade espiralada. As partes, em número de sete, são intituladas: A chegada, Na cama, O levantar, O banho, Café da manhã, O esporro, A chegada. Na primeira, vemos a mulher, sem ser nominada, chegando ao sítio, sendo que sua chegada parece fazer parte de uma rotina já consolidada. Na segunda, vemos o encontro social e íntimo do casal, que ocorre com plasticidade teatral no que diz respeito aos atos da relação amorosa. $\mathrm{O}$ terceiro quadro envolve o despertar natural e calmo do casal que parece estar satisfeito com a relação íntima que teve à noite. No quarto, acompanhamos o ritual do banho do casal, sendo que a mulher envolve o narrador com cuidados quase tão mais maternais que propriamente de amante. No quinto capítulo, acompanhamos o café da manhã, sendo que a relação de ambos ainda parece ser pautada pela contenção tanto dialógica quanto amorosa. No sexto quadro, vemos o surgimento de condições para a explosão colérica que dá título ao livro, sua consolidação e o desfecho da situação de enfretamentos emocionais e racionais da dupla. No sétimo capítulo, há a repetição do título inicial. Uma nova chegada da mulher ao sítio acontece. Nesse capítulo, muda-se a voz narrativa. Agora é a própria mulher que toma conta do relato, o que deslo- 
ca a estrutura circular para uma dinâmica diferenciada que é a espiralada. Ou seja, parece que se repetem as situações narrativas, mas o movimento traz um elemento diferencial. Uma mudança aconteceu na narrativa principal, que gera condições para transformar o contexto dos amantes em negociação existencial.

Caso observássemos as subjetividades representadas na/pela narrativa como identidades fixadas por variáveis comportamentais e existenciais, estaríamos no nível da crença nas características indefectíveis do que as rostidades ocasionariam nessa realidade ficcional. As personagens, tanto actantes quanto narradoras, estariam naquele campo de nosso conhecimento previsível que teríamos delas. Por rostidade, compreendemos aquilo que Gilles Deleuze e Félix Guattari observam sobre formações subjetivas ou de qualquer outra realidade essencializada:

Uma criança, uma mulher, uma mãe de família, um homem, um pai, um chefe, um professor primário, um policial, não falam uma língua em geral, mas uma língua cujos traços significantes são indexados nos traços de rostidade específicos. Os rostos não são primeiramente individuais, eles definem zonas de frequência ou de probabilidade, delimitam um campo que neutraliza antecipadamente as expressões e conexões rebeldes às significações conformes. (DELEUZE; GUATTARI, 1996, p. 32)

O conceito de rostidade supõe, então, um campo identitário criado na relação de causalidade entre situações e espaços e a consequente subjetividade fixada $a$ priori. Ou seja, de acordo com as qualidades pré-fixadas de modo histórico dos espaços nos quais os sujeitos estão inseridos, formam-se as cartografias das pessoas que ali se locomovem, atuam e constroem seus esquemas comportamentais e de vida paradigmática. Rostidade, nesse sentido, estaria ligada de modo fixo aos sentidos que estão ancorados por toda uma disposição política de estrutura, funcionalidade e possibilidades relacionais inscritas em formações discursivas que transmitem, de modo cotidiano, sinais de construtos aparentemente naturalizados pelas convenções e hábitos.

Teríamos, quando pensamos em espaços e subjetividades pré-construídos e que deles o sujeito con- formado por vezes não tem consciência, um construto identitário que também é discutido por Stuart Hall, em referência ao que seria o sujeito iluminista. A episteme de Hall possui solo um tanto diferenciado da de Gilles Deleuze e Félix Guattari, pois, nela a singularidade identitária carece da mobilidade performática que dinamiza, em certos contextos, a natureza da rostidade. Para Hall, uma ideia já clássica de identidade centrada seria aquela que abrange

[o] sujeito do Iluminismo [que] estava baseado numa concepção da pessoa humana como indivíduo totalmente centrado, unificado, dotado das capacidades de razão, de consciência e de ação, cujo "centro" consistia num núcleo interior, que emergia pela primeira vez quando o sujeito nascia e com ele se desenvolvia, ainda permanecendo essencialmente o mesmo - contínuo ou "idêntico" a ele - ao longo da existência do indivíduo. (HALL, 2001, p. 10-11)

Ao lado de outras categorizações mais abertas da individualidade discutida por Hall, percebemos que essa primeira categoria parece dominar uma forte tendência ao se pensar a temática, ainda mesmo em nossas épocas de desdobramentos das epistemes, da modernidade nas epistemes pós-modernas e correlatas.

Dadas as reflexões sobre formação subjetiva e espacial sob o enfoque da rostidade, as identidades essenciais, portanto fixas já de modo apriorístico e com ares de fenômeno natural e não histórico, teríamos que o narrador-personagem de um Um copo de cólera poderia ser observado em uma suposta compleição subjetiva fechada no conjunto de características assinaláveis como: um homem que se isola das modernidades urbanas em seu projeto de mundo pastoril; um homem herdeiro de tradições étnicas que valorizam comportamentos tradicionais de gênero, como a crença de que o gênero feminino deve se submeter aos rigores falocêntricos; um homem que valoriza sua engenharia existencial, montada por suas crenças e leituras em detrimento de qualquer outra engenharia sociocultural que lhe possa exigir condição dialógica ou submissão; um homem que apresenta uma deprimente psicopatologia que lhe traz convulsões psicofísicas e o coloca à mercê da ajuda de pessoas de outras culturas. Ou seja, pela visão 
de uma rostidade conformada, e de baixa mobilidade performática, acompanharíamos o relato de um sujeito que parece enlouquecer diante das exigências que as relações interculturais lhe exigem.

Tal narrativa faz uso de vários dados paratextuais, como observamos em uma das epígrafes gerais: "Ninguém dirige aquele que Deus extravia" (NASSAR, 1978, p. 5). O autor usa, por exemplo, essa citação do Alcorão para balizar sua proximidade com a cultura libanesa heterogênea nos aspectos religiosos, junto aos dados complementares aos literários, que são aqueles de sua própria biografia; parece então que aí acompanhamos os efeitos colaterais do processo de assimilação cultural. Assimilação essa que deveria acontecer entre um homem, que é envolvido por valores, crenças e preconceitos de uma cultura típica, a libanesa, frente ao encontro com as culturas da região para onde é forçado a migrar, que é a geografia do espaço urbano e do espaço rural do estado de São Paulo, com os seus agentes sociais.

Um dos efeitos desse heterogêneo processo de assimilação parece ser o quadro insidioso que se coloca na narrativa. O narrador-protagonista, no mais longo capítulo da narrativa que é $O$ esporro, parece ser acometido pela loucura, em sua frente acarretada pela emoção da cólera e pela sua contraparte psiconeurológica que seriam as convulsões de fundo epiléptico. Estaria aí configurada uma linha de força de rostidade de nosso chacareiro?

Um Copo de cólera traz-nos exemplos de concisão literária e, ao mesmo tempo, exemplos da verborragia linguística, que podem nos exemplificar encontros entre culturas heterogêneas que necessitam cultivar o ponto de equilíbrio para a coexistência tolerável. Seus núcleos accionais, como sumariamos acima, envolverão um casal em relação parental diferenciada. De focalização predominantemente autotélica, o texto apresenta-nos um homem, por volta de seus quarenta anos, vivendo isolado em um sítio, que se relaciona com uma mulher, jornalista e ativista em causas político-sociais. O casal de personagens não é nominado. Ele e Ela são as referências para localizarmos as duas subjetividades que se encontrarão em uma temporalidade breve, mas de intensidade conflituosa, apresentando instigantes possibilidades de negociações culturais variadas.
Ele e Ela não são casados de modo convencional. Lembram-nos amantes que são íntimos de longa data, não acreditam na instituição do casamento, mas se esforçam por manterem os vínculos de intimidade amorosa. Essa relação amorosa é disposta em uma temporalidade narrativa condensada, que perfaz o período de poucas horas. Temporalidade esta que, no plano do discurso, ocorre de modo aparentemente calmo e sequencial. Poucas e breves anacronias dão-nos conta de fatos que poderiam explicar as circunstâncias que causam os confrontos presentes na narrativa principal.

Simplicidade de enredo, apesar da urdidura da linguagem usada, e da polissemia intensa de ações, sensações e afetos desencontrados, marca essa segunda narrativa de Raduan Nassar. Nela, a instituição da família é vista através de ângulo diferenciado de, por exemplo, sua primeira narrativa que foi Lavoura Arcaica. Tal esfera existe e sobredetermina os actantes, mas suas bases já são feitas por outros valores, tais como a preservação do diálogo no seio do universo íntimo de cada um, do lugar social profissional de cada um, das crenças religiosas (colocadas de modo bastante implícito) de cada um. O casamento, nesse contexto, é feito na esfera provisória do acordo entre constituições subjetivas aparentemente exclusivas que, por um impulso contraditório, procuram atenuar as diferenças, sem que, no entanto, elas desapareçam.

Desse contexto parece fácil retirarmos exemplos que colocam o protagonista de Um copo de cólera na berlinda do registro comportamental e racional necessários aos contextos interculturais. Afinal, ele não demonstra enlouquecer-se quando perde o controle sobre sua fala e sobre seu corpo no meio de gritos, convulsões e perda de sentidos? O que o encontro de culturas diferentes (Ele com sua cultura de origem predominantemente árabe, amor pela vida campesina, valores patriarcais e machistas. Ela, com sua cultura ocidental, amor pela vida urbana e notórios valores feministas) tem a nos contar sobre os corpos, as espacialidades e as formações subjetivas em que estamos inseridos e, por vezes, nem temos consciência deles? 


\section{A cólera na espacialidade heterotópica}

O espaço é de fato um dos dispositivos relevantes nas engenharias de identidade transversais, aquelas feitas por vetores múltiplos de formações enunciativas sociais, culturais e políticas? São fenômenos naturais ou construídos em longas diacronias, carregando em sua constituição valores sociais, políticos e culturais dos quais, por vezes, sequer deles temos consciência?

Ele, protagonista de nossa narrativa de estudo, é um sujeito que já conseguiu construir certa engenharia de inserção espacial, apesar de tal espaço estar no contexto dos diálogos necessários com a multiculturalidade estrangeira. Construiu, mesmo assim, sua chácara com grande desvelo e realmente mergulha nessa espacialidade desejosamente bucólica, como acompanhamos no fragmento:

\begin{abstract}
O sol já estava querendo fazer coisas em cima da cerração, e isso era fácil de ver, era só olhar pra carne porosa e fria da massa que cobria a granja e notar que um brilho pulverizado estava tentando entrar nela, e eu me lembrei seu jeito de falar, que "o calor de ontem foi só um aperitivo", e eu sentado ali no terraço via bem o que estava passando, e percorria com os olhos as árvores e os arbustos do terreno, sem esquecer as coisas menores do meu jardim, e era largado nessa quieta ocupação que sentia os pulmões me agradecerem os dedos cada vez que o cigarro me subia à boca, e ela onde estava eu sentia que me olhava e fumava como eu, só que punha nisso uma ponta de ansiedade, certamente me questionando com a rebarba dos trejeitos, mas eu nem estava ligando pra isso, queria era o silêncio, pois estava gostando de demorar os olhos nas amoreiras de folhas novas, se destacando da paisagem pela impertinência do seu verde (bonito da vida!). (NASSAR, 1978, p. 27-28)
\end{abstract}

Pensamos, assim, que, para compreender melhor os variados sentidos que conformam as rostidades em deslocamento que Um copo de cólera nos propicia, seja necessário acompanharmos algumas reflexões sobre essa categoria de base que é a espacialidade em seus sentidos históricos e sociais.
Com implicações sócio-político-culturais, abordamos a teorização que Michel Foucault elabora sobre o tema. De uma pequena, porém intensa conferência publicada no ano da morte do pensador, intitulada $\mathrm{Ou}$ tros espaços, acompanhamos uma vibrante taxionomia, paradoxalmente flexível, da espacialidade que também funciona como um operador analítico que poderemos usar nesse estudo.

Foucault parece continuar o seu trabalho de arqueologia que é movido pela preocupação em compreender a gênese de teias teóricas, conceitos, construtos institucionais, grades disciplinares e afins. Aqui, sua preocupação é a distinção de uma cronotopia da espacialidade. Inicia por demonstrar que a noção de espaço, até a Idade Média apresentada através de rígida estrutura hierarquizada, foi dessacralizada em seus valores predominantemente teológicos, na consolidação das perspectivas renascentistas. No entanto, tal laicização do espaço deu-se mais no plano teórico do que prático. Essa desconstrução de valores tradicionais - religiosos e aristocráticos -, segundo o autor, é um projeto de avanços científicos e acadêmicos que ainda está em curso, mesmo na contemporaneidade.

Tal processo de compreensão lógica e social do espaço, para Foucault, evolui de uma perspectiva fechada para a relacional. Assim, a noção de espaço sai do contexto de uma definida localização - o espaço unitário, coeso e fechado -, para o contexto da extensão - aquele espaço marcado por um referencial localizado em uma rede de possibilidades de movimento -, até chegar ao contexto da posição - aquele contexto do espaço visto como posicionamento, no qual o aspecto relacional de seres, coisas e situações são mais marcados pelo aspecto da relação do que pela substância geográfica ou pelo movimento de individualização que territorializa determinada espacialidade.

Das possibilidades do espaço marcado de modo provisório pela posição, teríamos aqueles conhecidos como: os posicionamentos de passagem, os de parada provisória e aqueles de repouso. Esses espaços de posicionamento, por mais que possam ser fugidios em suas configurações pragmáticas, podem ser compreendidos, descritos, explicados e analisados por instrumentais quantitativos e qualitativos, como quaisquer outros 
métodos das ciências humanas e sociais. Ao lado desse instrumental teórico, o autor também nos fala do que seriam espaços diferenciados e bastantes peculiares.

Uma das categorias desses espaços agruparia os utópicos e os distópicos, no sentido de que não são moldados por realidades factuais determinadas, mas que comportariam características potencializadas de qualidades positivas e/ou negativas em espelhamento com aqueles espaços de posicionamento marcados pela realidade consensual. Outra categoria seria talvez das mais instigantes, a dos espaços heterotópicos. Para o autor,

[q]uanto às heterotopias propriamente ditas, como se poderia descrevê-las, que sentido elas têm? Seria possível supor, não digo uma ciência porque é uma palavra muito depreciada atualmente, mas uma espécie de descrição sistemática que teria por objeto, em uma dada sociedade, o estudo, a análise, a descrição, a "leitura", como se gosta de dizer hoje em dia desses espaços diferentes, desses outros lugares, uma espécie de contestação simultaneamente mítica e real do espaço em que vivemos; essa descrição poderia se chamar heterotopologia. (FOUCAULT, 2001, p. 415-416)

Esses espaços sintéticos, complexos e de espelhamento também invertido da realidade consensual, teriam cinco princípios: o da aparente universalidade, o da variação diacrônica, o da sobreposição de virtualidades espaciais heterogêneas, o da ruptura com contextos tradicionais e, por fim, o princípio das normatizações iniciáticas para o seu acesso. Desses espaços, duas heterotopias são definidas: a heterotopia de desvio e a de crise.

A primeira, mais comum em sociedades antigas, trata de comportamentos - no campo da purificação, da educação especializada e afins - que devem ser efetivados e controlados longe do convívio social que acontece nos espaços de posicionamentos cotidianos, particulares e públicos. A segunda, recorrente em contextos modernos e contemporâneos, é definida por comportamentos e situações que precisam de certo controle, de ajustes e contensões: "Aquela na qual se localizam os indivíduos cujo comportamento desvia em relação à média ou à norma exigida" (FOUCAULT, 2001, p. 416).
Interessa-nos aqui, de perto, essas categorizações do que seriam as heterotopias de desvio e a de crise, que abrangem os tempos da modernidade e o de nossa contemporaneidade. Voltamos, também aqui, a outra reflexão que Michel Foucault faz em seu clássico estudo sobre a loucura, abordando a famosa imagem da Nau dos Loucos.

Essa figura se arvora em nossa imaginação ao pensarmos nas modalidades que o Ocidente medievo e o renascentista possuíam dos nichos dos sujeitos não adequados às tradições de sua sociedade. A tal embarcação dos loucos, existindo em várias obras de ficção, também existiu na referencialidade histórica. Governos e comunidades usaram o mecanismo de expurgo como estratégias de controle da assepsia neurológica e da comportamental. Se o campo da medicina ainda era incipiente quanto ao tema, os campos social e político já se consolidavam nas formas mais pontuais de exclusão e invisibilidade dos sujeitos com problemas de adequação mental e social.

Tanto na Idade Média quanto no Renascimento, Michel Foucault (1978) nos descreve como as autoridades montaram seus mecanismos de organização social via exclusão de comportamentos diferenciados em relação às normas de um modelo ideal de bem-estar coletivo, sendo que vários desses comportamentos eram vinculados ao que se considerava loucura.

Assim, pessoas não produtivas para o contexto social - como os vagabundos, rebeldes, deslocados socialmente, portadores de deficiências variadas entre tantos outros - eram tiradas de seus lugares, colocadas em embarcações e levadas para lugares que as recebiam para tratamento ou então ficavam em constante peregrinação em contextos espaciais semelhantes a não lugares. Essas sociedades consideravam, pois, que se manteriam purificadas em relação a um lado obscuro e perigoso do ser humano, lado esse que faria frente aos seus princípios de beleza, de bem-estar, de supostos valores verdadeiros em relação ao ideal de organização para a produtividade inconteste. Foucault nos esclarece sobre a história dessas embarcações:

Um objeto novo acaba de fazer seu aparecimento na paisagem imaginária da Renascen- 
ça; e nela, logo ocupará lugar privilegiado: é a Nau dos Loucos, estranho barco que desliza ao longo dos calmos rios da Renânia e dos canais flamengos.

[...] Os loucos tinham então uma existência facilmente errante. As cidades escorraçavamnos de seus muros; deixava-se que corressem enfiados a grupos de mercadores e peregrinos. Esse costume era frequente particularmente na Alemanha: em Nuremberg, durante a primeira metade do século XV, registrou-se a presença de 62 loucos, 31 dos quais foram escorraçados. Nos cinquenta anos que se seguiram, têm-se vestígios ainda de 21 partidas obrigatórias, tratando-se aqui apenas de loucos detidos pelas autoridades municipais 23. Eram frequentemente confiados a barqueiros: em Frankfurt, em 1399, encarregam-se marinheiros de livrar a cidade de um louco que por ela passeava nu; nos primeiros anos do século XV, um criminoso louco é enviado do mesmo modo a Mayence. Às vezes, os marinheiros deixavam em terra, mais cedo do que haviam prometido, esses passageiros incômodos; prova disso é o ferreiro de Frankfurt que partiu duas vezes e duas vezes voltou, antes de ser reconduzido. (FOUCAULT, 1978 , p. 12, 13, 14)

O autor reflete sobre as razões da invenção e da operacionalidade do mecanismo político-social que é a Nau dos Loucos. Se ela funciona como mecanismo ordenador e de preservação do bem-estar social idealizado, não é usada por todas as sociedades, pois algumas já elaboram e fazem funcionar os mecanismos da internação sanatorial para cuidarem de seus sujeitos em enfretamento com a ordem hegemônica e/ou portadores de deficiências físico-mentais.

De qualquer forma, o indivíduo supostamente louco é retirado de seu locus original e colocado em circulação por terras desconhecidas. E quando a tal embarcação não encontra seu porto seguro, essa circulação transforma-se em situação fixa que seria a eterna circulação.

A possibilidade de uma espacialização pontual foge do destino das pessoas com o rótulo de pessoas loucas. Então, uma das possibilidades de existência da Nau dos Loucos é o eterno trânsito pelo elemento aquático que, se não auxilia verdadeiramente os seus usuários forçados, parece preservar a ordem e a saúde das cidades fincadas em solo firme, qual um aviso de que saúde e ordem exigem o sacrifício de identidades diferenciadas por questões orgânicas ou comportamentais que dizem respeito a valores e crenças não aceitas pelo modelo.

No desenvolvimento de seu relato histórico e crítico, Foucault indicará que uma das funcionalidades da tal Nau dos Loucos será deslocada para a construção dos sanatórios, que hoje ainda nos são instituições familiares. Ou seja, a purgação e o controle do lado obscuro da humanidade terá seu curso na história e deles teremos conhecimentos mais ordenados e supostamente científicos de como demonstram o desenvolvimento de saberes como os da fisiologia, da neurologia, da psiquiatria, da psicologia, da psicanálise; enfim, conhecimentos sistemáticos sobre a saúde humana e a doença, seja ela física ou psíquica, avolumam-se, consolidam-se e adquirem o respeito político na preservação da ordem e do bem-estar populacional.

No entanto, certa forma e funcionalidade da Nau dos Loucos parecem ter se imbricado em alguns contextos e relações sociais, sem dela nos darmos conta facilmente. Exclusão, vigilância e controle de comportamentos considerados inoportunos por agentes que cuidam de padronizações da ordem coletiva seriam daquelas estratégias características que vemos se perpetuar, mesmo que os espaços não sejam físicos, como aqueles de embarcações de expurgos, ou de construções mais sólidas como sanatórios, clínicas, hospícios, prisões e outros espaços afins.

Um desses contextos parece ser aquele do campo das relações entre etnias diferentes (práticas multiculturais de determinados grupos sociais) e gêneros diferentes (sexo como representação sociocultural), diferentes em processo de encontros e assimilações, nos quais uma vertente cultural vê-se frente às pressões e intimidações sociais e culturais de outra vertente consolidada e hegemônica.

Aqui, voltamos ao nosso enredo de Um copo de cólera, para observarmos e refletirmos sobre como se instaura a situação de aparente loucura do protagonista e como se conforma a espacialidade rural na qual tal sujeito se insere, sendo que tal espaço, no qual ocorrem embates de assimilação sociocultural, parece se assemelhar a alguns aspectos da famosa Nau dos Loucos.

No texto de Raduan Nassar, uma atualização enviesada da Nau dos Loucos poderia ser o espaço rural 
do chacareiro e sua capacidade de gestação de estratégias de subjetivações. Esse espaço se configura como a junção das heterotopias de desvio e de crise, que apontamos anteriormente quando mencionamos os levantamentos e as reflexões históricas foucaultianas.

Nesse espaço ficcional estariam as características de expurgo da identidade instável em um lugar em que se poderia assegurar seu reaprendizado quanto à ordem desejada pelos valores que a companheira urbana representa, ou simplesmente as da manutenção da identidade campesina, tradicional e autocentrada, afastada do grupo de indivíduos que não se adequam a tal ordem.

Nosso protagonista mora em uma chácara, como mencionamos antes, e cultiva hortaliças e cria animais. Sua integração com a produção rural parece bastante estável e meticulosa como a narrativa nos insiste em pontuar. Trata-se, pois, de um descendente de imigrantes que, baseando-nos nos dados da sua possível etnia libanesa, estaria em processo de assimilação cultural positiva.

A narrativa, no entanto, nos oferece o capítulo extenso e intenso do Esporro, no qual vemos a possível adaptação tranquila desmoronar-se frente à visita da mulher que representa os princípios e valores da cidade e de certo estrato da cultura brasileira. Nesse encontro, observamos que o espaço campesino parece funcionar como o espaço do expurgo e do desterro para os quais Ele é atirado. Sua Nau dos Loucos parece ser o próprio sítio que constrói com as tentativas de assimilação da cultura que lhe rodeia e insiste em penetrar-lhe o corpo e a consciência.

A chácara e seu dono formariam o espaço e a subjetivação do desvio e da crise, quando vistos em suas possibilidades de existência insulada em si mesma. $\mathrm{O}$ caráter do desvio subjetivo quanto à cultura dominante surge pelos fatos de sua origem cultural: sua tradição de cultivar o solo e seus desideratos, bem como o fato de que seus valores religiosos o empurram para posições falocêntricas que não aceitam certas autonomias e liberdades para as identidades femininas em curso. $\mathrm{O}$ caráter de crise parece apontar para o aspecto de que tais enfrentamentos tenderão a chegar a algum resultado que pode indicar sua exclusão total na constante navegação de sua embarcação do espaço que é transfor- mado em entrelugar - o lugar entre a cidade e o campo, entre a tradição e a inovação/assimilação da cultura diferente - ou, então, a formulação de acordos nos quais novas subjetivações tomarão a posição das identidades inflexíveis que um e outro encenam.

Ainda na influência da Nau dos Loucos, como vemos o surgimento da psicopatologia social do protagonista? Agregamos o caráter sociocultural ao termo psicopatologia porque sentimos que a narrativa de Raduan Nassar aponta mais para tais questões do que para aquelas do campo neurológico e psiquiátrico. Apesar da presença de fortes sintomas psicofísicos que são referendados por algumas C.I.D.s do manual de transtornos mentais da OMS - Organização Mundial de Saúde (1993), temas que também acompanhamos em SAMPAIO (1998), acreditamos que o comportamento sintomático de nosso chacareiro encaminha-se mais para os efeitos advindos dos encontros de culturas diferentes; encontros esses que podem ocasionar efeitos somáticos de diversas ordens e nos ensinam que o processo de assimilação da outridade também pode criar condições em que sentimentos de cólera e empatia paradoxalmente caminham juntos.

Esse sujeito parece ter o controle sobre as técnicas de produção de sua chácara e sobre a compreensão da estruturalidade e funcionalidade de sua existência supostamente pacata e de acordo com os seus princípios e valores, mesmo no que seria uma terra estrangeira que o acolhe com parcimônia. No entanto, na manhã após o encontro rotineiro com sua amante da cidade, percebe que as formigas cortadeiras tinham atacado uma cerca viva do seu espaço cuidadosamente montado. Descontrola-se de modo singular e abruptamente coloca veneno no olho do formigueiro para contornar e controlar a situação de desiquilíbrio que surge tanto em seu espaço físico quanto em sua subjetividade em curso. Se as formigas aterrorizam seus cultivares campesinos, outra força desestabilizadora toma-lhe conta dos pensamentos, emoções e ações. Uma densa neblina toma-lhe o funcionamento cerebral, o que demonstra o começo do sentimento de cólera:

$[\mathrm{M}]$ as meus olhos de repente foram conduzidos, e essas coisas quando acontecem, a gente 
nunca sabe bem qual o demônio, e, apesar da neblina, eis o que vejo: um rombo na minha cerca-viva, ai de mim, amasso e queimo o dedo no cinzeiro, ela não entendendo me perguntou “o que foi?", mas eu sem responder me joguei aos tropeções escada abaixo (o Bingo, já no pátio, me aguardava eletrizado), e ela atrás de mim quase gritando "mas o que foi?", e dona Mariana corrida da cozinha pelo estardalhaço, esbugalhando as lentes grossas, embatucando no alto da escada, pano e panela nas mãos, mas eu nem via nada, deixei as duas pra trás e desabalei feito louco, e assim que cheguei perto não aguentei "malditas saúvas filhas-da-puta", e pondo mais força tornei a gritar "filhas-da-puta, filhas-da-puta", vendo uns bons palmos de cerca drasticamente rapelados, vendo uns bons palmos de chão forrados de pequenas folhas, é preciso ter sangue de chacareiro pra saber o que é isso, eu estava uma vara vendo o estrago, eu estava puto com aquele rombo, e só pensando que o ligustro não devia ser assim essa papa-fina, tanta trabalheira pra que as saúvas metessem vira-e-mexe a fuça, e foi numa rajada que me lancei armado no terreno ao lado. (NASSAR, 1978, p. 28- 29)

A cerca viva, construída metodicamente, era ameaçada; o que funciona também como alegoria para $\mathrm{o}$ encontro entre os humanos. $\mathrm{O}$ quadro peculiar, que aproxima o espaço da chácara àquela Nau dos Loucos, instaura-se com a estratégia de enfrentamento acionada pela mulher e sua contrapartida. A representante de certa ordem urbana e feminista, e da contemporaneidade em que valores tradicionais se esgarçam e têm diminuído sua hegemonia, deseja também marcar seu território, avaliando o comportamento descontrolado do homem com o qual se relaciona, além de estabelecer novas relações de hierarquia social e cultural. Do alto de seu registro de poder, ela avalia o companheiro e o alerta para sua fragilidade e inadequação que abririam sua condição para o comportamento de cisão entre o eu e o outro, inserindo-o no quadro psicopatológico, como observamos:

Não é para tanto, mocinho que usa a razão, e eu confesso que essa me pegou em cheio na canela, aquele "mocinho" foi de lascar, ainda mais do jeito que foi dito, tinha na observação de resto a mesma composta displicência que ela punha em tudo, qualquer coisa assim, no caso, que beirava o distanciamento como se isso devesse necessariamente fundamentar a sensatez do comentário, e isso só serviu pra me deixar mais puto, "pronto" eu disse aqui comigo como se dissesse "é agora", eu que ficando no entrave do "mocinho" podia perfeitamente lhe dizer "fui manipulando pelo tempo" (se bem que ela não fosse lá entender que vantagem eu tirava disso, passando-lhe também um sabão pelo uso, enfadonho no fundo, da ironia maldosa. (NASSAR, 1978, p. 31-32)

Esse enfrentamento, com base nas estratégias de empoderamento pessoal e social de cada um, cria o início do Esporro. Esse esporro avança por muitas páginas dessa pequena narrativa e conforma-lhe o cerne. O sentimento de cólera se apresenta aí nas descrições, reflexões e avaliações da capacidade de conhecimento e nas possibilidades de cada um dos dois se posicionar frente às circunstâncias das negociações exigidas por um cotidiano multicultural.

Formação cultural, postura diante das profissões, possibilidades de relacionamentos sociais amplos ou restritos, controle das pulsões sexuais, capacidade de construir condições para o locus e o socius relacionais e positivamente produtivos, são situações colocadas em jogo no longo enfretamento no qual o casal se lança intensamente. Os dois não medem o ímpeto discursivo e as consequências dos ataques virulentos que, mais do que auxiliarem uma possível relação dialógica construtiva, poderiam causar um rompimento final na relação entre o homem e a mulher e entre duas formações discursivas que refletem nichos socioculturais diferentes. O espaço rural hibridizado, tal qual a Nau dos Loucos, configura-se com as causas e consequências da cólera que encobriria o salutar exercício da razão consensual.

No entanto, um acontecimento físico inusitado ocorre. O protagonista, no ápice de sua fúria, sofre um surto convulsivo. Perde o controle psicofisiológico de si mesmo, sendo necessário que seja auxiliado pela companheira e pelo casal de serviçais:

[E]u só sei que de repente me larguei feito um fardo, acabei literalmente prostrado ali no pátio, a cada enfiada nas mãos, os olhos formigando, me sacudindo inteiro numa tremenda explosão 
de soluços (eram gemidos roucos que eu puxava lá do fundo), até que meus braços foram apanhados por mãos rústicas e pesadas, a dona Mariana de um lado, o seu Antônio do outro, ele caladão e desajeitado, ela desenvolta apesar do corpo grosso, procurando logo me distrair com seu relato, me falando numa voz de afago que eu não podia deixar de passar pelas coelheiras "antes de zarpar lá pra São Paulo", que ela estava "perplexa" co’a ninhada da Quitéria, “a 'menina' teve treze na primeira cria, treze! Quem diria”, e me lembrando que “o pai é o Pituca, aquele malandro de coelho, tão velho e ainda procriando", "perplexa" repetia a dona Mariana, no acalanto, só mudando o tom pra passar à meia-voz uma raspança no marido que não punha o mesmo empenho que ela, os dois tentando me erguer do chão como se erguessem um menino. (NASSAR, 1978, p. 77-78)

Desse modo, a ambiência causada pelo destempero violento do sentimento de cólera é colocada como que em suspenso. Uma trégua entre as mundividências heterogêneas parece surgir. A Nau dos loucos se acalma, dando margem a formações de outras possibilidades discursivas e subjetivas, que talvez objetivem diálogos entre olhares e modalidades de vida diferentes, bem como novos espaços existenciais e paradigmas estéticos que a narrativa ficcional parece nos deixar vislumbrar.

\section{Estratégias para produção de identidades transversais}

A Nau dos Loucos possui uma origem híbrida, segundo Michel Foucault. No mundo antigo está vinculada às aventuras de heróis míticos que procuram soluções para manter a ordem estabelecida de suas sociedades, frente aos ininterruptos problemas e desequilíbrios de que o cotidiano é feito. Naus com heróis em suas provações e trabalhos necessários funcionam, pois, como as Naus dos Sensatos, como aquela dos Argonautas que procuravam pelo velocino de ouro. Tal simbolismo se estende do mundo antigo para a Idade Média e para o Renascimento, indicando a necessidade de modelos variados de comportamentos que conheçam, valorizem e lutem pelos princípios hegemônicos da ordem coletiva estabelecida:
[...] ressuscitado entre os grandes temas míticos e ao lado de Blauwe Schute de Jacob Van Oestvoren em 1413, de Borgonha. A moda é a composição dessas Naus cuja equipagem e heróis imaginários, modelos éticos ou tipos sociais, embarcam para uma grande viagem simbólica que lhes traz, senão a fortuna, pelo menos a figura de seus destinos ou suas verdades. (FOUCAULT, 1978, p. 14)

Há, pois, uma mitologia que se mostra dialética e crítica nas representações que faz. Um campo para a sensatez, que constrói e mantém determinada ordem, e um campo para as psicopatologias, que funcionaria como contraponto coercitivo, destrutivo ou deslocador para essa ordem.

No sentido em que aqui exploramos a questão da loucura, em relação à narrativa de Nassar e como um desiquilíbrio também de ordem social, cultural e política, observamos que o aspecto antropológico da assimilação pode abranger essas duas significações contraditórias: a sensatez e a insensatez nos encontros étnicos e afins.

Como vimos anteriormente, com auxílio das reflexões de Jardim (1999), o processo de assimilação cultural exige, para o seu curso satisfatório, que as duas partes envolvidas tenham possibilidades igualitárias de diálogo para que novas relações e circunstâncias sociais e culturais se estabeleçam e sejam capazes de criar contextos equilibrados, apesar da heterogeneidade dos componentes. Uma parte envolvida não deveria submeter a outra parte ao que considera ser a estrutura vivencial única e legítima, o que ocasionaria, caso tal imposição seguisse seu curso, condições para que desequilíbrios de várias ordens surjam, inclusive os psicopatológicos, de origem mais social que neurológica. Como esse equilíbrio, apesar de frágil e de constante construção, poderia acontecer em nossa narrativa de estudo?

Em Um copo de cólera vemos a personagem Ele supervalorizando os hábitos patriarcais de sua cultura familiar, quando exige um comportamento subserviente de sua companheira Ela. A mulher da nova parentalidade, porém, assume um comportamento típico do feminismo contemporâneo, sendo que as consequências dessa assumência política de seu próprio corpo apontam sua independência ideológica, financeira e afetiva. Ele, no entanto, cobra que Ela assuma a relação 
de modo tradicional, que ela tome conta dos afazeres domésticos de sua chácara, da gerência dos serviçais domésticos, da roupa e da comida de seu companheiro, e de todo o corolário que a condição feminina subserviente exige. No entanto, Ela não admite o retrocesso comportamental, a perda de seu lugar social de agente ativo e enfrenta o companheiro de forma franca e direta, o que também gera o transbordamento da cólera do macho desobedecido.

Ela, além de não assumir o lugar social feminino e estereotipado exigido pelo companheiro, contesta os agenciamentos discursivos conservadores e paradoxalmente anárquicos do companheiro em relação a temas como trabalho, ação política, conhecimento, entre outros. Eis um exemplo do enfrentamento de Ela aos desmandos e dogmatismos do companheiro:

Só um idiota recusaria a precariedade sob controle, sem esquecer que no rolo da vida não interessam os motivos de cada um - essa questãozinha que vive te fundindo a cuca - o que conta mesmo é mandar a bola pra frente, se empurra também a história com mão amiga dos assassinos; aliás, teus altíssimos níveis de aspiração, tuas veleidades tolas de perfeccionista tinham mesmo de dar nisso: no papo autoritário dum reles iconoclasta - o duma classe agônica... Sai de mim, carcaça e logo ela taxava minha performance catártica ("pura catarse" ela engrolou), palavra c'um terrífico poder demolidor e que - pelo uso imprudente, ou pelo abuso - transformava o próprio cérebro da pilantra num cogumelo nuclear, mas eu de novo dei a volta por cima, deixei inclusive a "parafernália" pra trás (bola pra frente!) e fui empurrando a minha história, equacionando uma álgebra tropical, ardente como nas origens (sangue e areia) um operação perfeita por não dispensar os valores positivos da pilantra. (NASSAR: 1978, p. 55-56)

A característica típica do mundo árabe, que diz respeito à autoridade dogmática do marido, do pai, do homem em geral em relação às mulheres, crianças e velhos, é deslocada para uma nova dimensão de relações. Um comportamento estereotipado é colocado no crivo da desconstrução, apesar de Ele reagir com agressividade desmesurada a essa nova exigência do sujeito diaspórico.
Autoridade dogmática, baseada em textos religiosos (seja a Bíblia ou o Alcorão), patriarcalismo fixo (cuja base falocêntrica não admite divisão de poderes com outros gêneros), exigência de se formar uma família fechada sobre si mesma (ou então agrupada em uma rede de famílias de mesmo credo e cultura), formam um conjunto denso de postulados tipificadores do mundo árabe, bem como de várias outras sociedades, em sua dimensão libanesa presentes nessa narrativa ficcional.

Quando observamos essas emergências do que seriam as peculiaridades culturais do contexto em estudo, perguntamo-nos sobre como é constituída a condição existencial desse povo libanês, que, como tantos outros, encontra-se em franca situação de diáspora e de posterior reterritorialização. O Ele de nossa diegese representa sua família ancestral, sua religião oficial, sua cultura supostamente homogeneizada, sua nação aparentemente unificada. Porém, nas movimentações pragmáticas, suas cartografias subjetivas formam-se em constantes e variados devires (DELEUZE; GUATARRI, 1995) que exemplificam os encontros-confrontos de cultura diferentes em condições provisórias que anseiam por uma manutenção mais confortável de suas identidades.

A constituição ontologicamente rizomática de tais fenômenos, no entanto, impende o corte dos fluxos cartográficos do que seriam identidades familiares, religiosas, culturais, nacionais e subjetivas. Semelhante ao rizoma do mundo botânico, as instituições sociais são criadas de modo heterogêneo, provisório e em constante processo de transformação. Suas constituições verticais, cêntricas e essencializadas não passariam, pois, de situações provisórias criadas e mantidas por forças políticas repressoras e alienantes.

Nesse plano de reflexão sobre processos de subjetivação, ao lado da perspectiva de rostidade, em seus aspectos de territorialização e de desterritorialização, refletidas por Deleuze e Guattarri (1995), como desenvolvemos acima, refletimos, também, sobre o conceito de diáspora, na perspectiva de Stuart Hall $(2003,2006)$, um dos principais nomes dos estudos culturais ingleses. Para esse autor, 
[e]sta é a sensação familiar e profundamente moderna de deslocamento, a qual - parece cada vez mais - não precisamos viajar muito longe para experimentar. Talvez nós sejamos, nos tempos modernos - após a Queda, digamos - o que o filósofo Heidegger chamou de unheimlicheit - literalmente, não estamos em casa”. [...] Já que esta é uma questão conceitual e epistemológica, além de empírica, o que a experiência da diáspora causa a nossos modelos de identidade cultural? Como podemos conceber ou imaginar a identidade, a diferença e o pertencimento, após a diáspora? Já que “a identidade cultural" carrega consigo tantos traços de unidade essencial, unicidade primordial, indivisibilidade e mesmice, como devemos pensar as identidades inscritas nas relações de poder, construídas pela diferença, e disjuntura? (HALL, 2006, p. 27-28)

O “não estar em casa” é visto como condição inerente ao complexo e movente campo identitário. Nesse ponto, observamos que o protagonista de Um copo de cólera encontra-se em situação diaspórica. Aquilo que seria sua base nacional, familiar, cultural e subjetiva está como que exilado em solo brasileiro, o que causa perturbação considerável à constituição subjetiva desse personagem. O sentimento de unicidade do sujeito é frequentemente questionado pelo encontro com uma frente cultural que não se conhece ainda de modo satisfatório ou na qual o sujeito não sabe como agir pragmaticamente perante o processo de ressocialização cultural.

Ele, em Um copo de cólera, esforça-se para preservar o seu olhar dessa necessária contaminação cultural, ao mesmo tempo em que tentar fazer acordo com uma mulher que representa aquilo que seria a cultura típica de certo estrato da sociedade urbana brasileira.

No entanto, Stuart Hall $(2003,2006)$ ainda nos ensina que a identidade cultural, bem como seus derivativos, não passa de narração inventada por um conjunto de agenciamentos políticos e afins. Essa inventividade abrange também a identidade nacional, a identidade religiosa, a identidade de gênero, a identidade pessoal centrada e suas consequências políticas, e, por fim, a formação de identidades transversais ou parciais.

Todas essas constituições seriam, mesmo quando localizadas em um pretenso espaço existencial natural, situações temporárias e históricas de organização social.
Sua constituição não é natural como os fenômenos da natureza, já que são invenções humanas no decorrer de uma complexa e política cronotopia. Se tais realidades socioculturais são provisórias, sua transitividade é frequentemente mascarada pelos órgãos de controle que lhes impõem uma roupagem de situações substantivas, cêntricas e imutáveis. Se por um lado essas constituições acarretam a sensação de conforto e de segurança diante do material identificatório conhecido e controlado, por outro lado elas podem funcionar como força que inibe a identificação com grupos étnicos diferentes, pois esses grupos trarão hábitos e valores estranhos para a relação de encontro e, ao mesmo tempo, de confronto.

Grupamentos étnicos, em situação de diáspora, são obrigados, apesar dos esforços de manter suas supostas identidades culturais intactas, a compactuar com aquilo que seria a identidade cultural do lugar vivencial escolhido, ou imposto, como nova casa. Este movimento de acordos é necessário para que o "estrangeiro" constitua condições de sobrevivência pragmática no lugar para o qual se desloca. Em um primeiro momento, então, surgem oscilações nos hábitos e valores que precisam ser controlados para que a organicidade do grupo étnico, em transição, não corra risco de ter sua identidade padronizada, mesmo que através das hibridizações intensas, destruídas.

Ainda acompanhando Hall (2003, 2006), sabemos que os grupos étnicos normalmente se deslocam para territórios desconhecidos e sofrem influência massiva dos grupos étnicos dos lugares escolhidos como nova moradia. Também sabemos que os grupos autóctones serão dinamizados pela influência dos imigrantes. Dessa forma, segue-se naturalmente o processo de deslocamento de populações pelo globo terrestre, através da evolução humana. Esse processo acarreta hibridização cultural de modo equilibrado, na medida em que se pode considerar o movimento como gerador de futuros compartilhados, mas também pode gerar situações de implacável desvalorização e até mesmo de destruição de segmentos minoritários de imigrantes.

A sistemática migração que consolidou a globalização do século XX gerou uma redefinição do mapa de culturas singulares no Ocidente e no Oriente. Em Um copo de cólera, o processo de inclusão sociocultu- 
ral dá-se de modo peculiar na dinâmica das luzes e das sombras, de comportamentos sensatos e insensatos, da lucidez e da loucura. Apesar de o personagem Ele tentar se isolar em uma chácara, mantendo suas tradições sob controle, existe o vínculo amoroso entre Ele e Ela, que abre as fronteiras e possibilita o diálogo crítico entre subjetivações diferenciadas.

O mundo da brasilidade tem, pois, acesso ao mundo da tradição libanesa, mesmo que essa relação seja estabelecida em bases conflituosas de ações e valores heterogêneos. Ele esforça-se por influenciar Ela em relação ao que acredita serem procedimentos comportamentais, profissionais, familiares, adequados ao verdadeiro exercício do saber viver. Em contrapartida, Ela insiste em reagir a essa influência, mostrando e programando uma reeducação sentimental e cultural para o companheiro um tanto dogmático, que funciona como exemplo do que seria o típico homem libanês e árabe, por extensão lata. E no quadro há a criação do lugar do encontro. Não mais um não lugar de subjetividades em guerra, mas um entrelugar de identidades transversais, cuja dependência intrapessoal pode ser balançada de modo mais justo, como acompanhamos no final da narrativa:

[A]travessei a peça toda, e só foi cruzar o corredor preu alcançar a porta ali do quarto, boiando vagamente à luz tranquila duma vela: deitado de lado, a cabeça quase tocando os joelhos recolhidos, ele dormia, não era a primeira vez que ele fingia esse sono de menino, e nem seria a primeira vez que me prestaria aos seus caprichos, pois fui tomada de repente por uma virulenta vertigem de ternura, tão súbita e insuspeitada, que eu mal continha o ímpeto de me abrir inteira e prematura pra receber de volta aquele enorme feto. (NASSAR, 1978, p. 81)

Nessa relação de influência mútua, com metodologia educada ou ríspida, o processo de desterritorialização e de reterritorialização segue seu curso usual da globalização, em sua frente de processos de subjetivações possíveis, que não destrói por completo as singulares das identidades culturais. Ao contrário da possível destruição que tais encontros podem ocasionar, criam-se novos complexos humanos, nos quais a regra dos vínculos passa a ser aquilo que Deleuze e Guatta- ri (1995) denomimam síntese disjuntiva inclusiva. Ou seja, identidades de qualquer natureza formam-se na precária constituição de heterogêneas características que surgem das diferentes realidades em fluxo rizomático e devires constantes, bem representados pelos agenciamentos de enunciação literária sobre os quais nos debruçamos.

\section{Considerações finais}

Em Um copo de cólera, apesar dos desencontros multiculturais entre o homem e a mulher, percebemos que o enredo encaminha-se para certo ponto de equilíbrio. Ponto esse no qual a sensatez da colaboração e da cooperação parece controlar os destemperos da cólera e de suas consequências; mesmo que esse equilíbrio seja temporário e frágil entre as cosmovisões diferentes. Tal situação pode ser acompanhada no último capítulo, em que a voz feminina também é capaz de assumir a enunciação:

E quando cheguei a casa dele lá no 27 , estranhei que o portão estivesse aberto, pois a tarde, fronteiriça, já avançava o escuro, notando, ao descer do carro, uma atmosfera precoce se instalando entre os arbusto, me impressionando um pouco a gravidade negra e erecta dos ciprestes, e ali ao pé da escada notei também que a porta do terraço se encontrava escancarada, $o$ que poderia parecer mais um sinal, redundante, quase ostensivo, de que ele estava à minha espera, embora o expediente servisse antes pra me lembrar que eu, mesmo atrasada, sempre viria. (NASSAR, 1978, p. 79-80)

O homem, que outrora encenava os movimentos de um isolamento prudente, performa agora certa subserviência infantil e aberta à novidade, enquanto a mulher encena o lugar sociocultural de mãe e de amante consciente de seu lugar de sujeito ativo. Tais comportamentos criam, pois, possibilidades de estratégias pactárias, que são necessárias à continuação e consolidação dos entrecruzamentos das duas culturas que, antes, insistiam nos protocolos da exclusão.

Assim, a vida complexa e densa, e ao mesmo tempo repleta de diafaneidades, segue seu curso por entre 
realidades rizomáticas feitas pelas dimensões da mesmice e da outridade. A Nau dos Loucos necessariamente não ficará a vagar por oceanos infindáveis, sem a possiblidade de atracagem em portos possíveis.

\section{Referências}

BAUMAN, Zygmunt. A vida fragmentada: ensaios sobre a moral pós-moderna. Tradução de Miguel Serras Pereira. Lisboa: Relógio D’Água Editores, 2007.

CADERNOS de Literatura Brasileira. Raduan Nassar. No 2. Rio de Janeiro: Instituto Moreira Salles, 1997.

DELEUZE, Gilles; GUATTARI, Félix. Mil Platôs: Capitalismo e Esquizofrenia. Tradução Aurélio Guerra Neto e Célia Pinto Costa. Vol.1, Editora 34, Rio de Janeiro, 1995.

. Mil Platôs: capitalismo e esquizofrenia. Vol. 3, Coordenação de tradução de Ana Lúcia de Oliveira. São Paulo: Editora 34, 1996.

FOUCAULT, Michel. História da loucura. Tradução de José Teixeira Coelho Netto. São Paulo: Editora Perspectiva, 1978.

"Outros espaços". In: Ditos e escritos. Vol. III. Organização e seleção de textos de Manoel Barros da Motta. Tradução de Inês Autran Dourado Barbosa. Rio de Janeiro: Forense Universitária, 2001.

GUATTARI, Félix. Caosmose. Tradução de Ana Lúcia de Oliveira e Lúcia Cláudia Leão. São Paulo: Editora 34, 1992.

HALL, Stuart. Da diáspora: Identidades e mediações culturais. Tradução de Adelaine la Guardia Resente et al. Minas Gerais: UFMG, 2003.

A identidade cultural na pós-modernidade. Tradução de Tomaz Tadeu da Silva e Guacira Lopes Louro. 11a ed., Rio de Janeiro: DP\&A Editora, 2006.

JARDIM, Denise Fagundes. "Quer comprar roupa feita?" A negociação de identidades sociais de migrantes palestinos. In: História em Revista - Dossiê Etnias. v. 5, dez. 1999, p. 49-93.

NASSAR, Raduan. Um copo de cólera. São Paulo: Livraria Cultura Editora, 1978.

OMS - Organização Mudial da Saúde. Classificação dos transtornos mentais e de Comportamento - CID 10. Porto Alegre: Artes Médicas, 1993.

SAMPAIO, J. J. C. Epidemiologia da imprecisão: processo saúde/doença mental como objeto da epidemiologia. Rio de Janeiro: Editora FIOCRUZ, 1998. 
